\title{
'Everything not saved will be lost': Videogames, Violence, and Memory in Contemporary Irish Fiction
}

This is an essay about Irish boys who die. Boys who play at dying and boys who play at killing. Boys who kill other boys, and boys who kill themselves. In Paul Murray's Skippy Dies (2010), Eimear McBride's A Girl is a Half-Formed Thing (2013) and Rob Doyle's Here Are the Young Men (2014), boys die as a result of illness, overdose and even murder. In all three novels, boys' bodies are portrayed as vulnerable; invaded by tumours, manipulated by abusers and destroyed by drugs. Small wonder then that these boys are also shown retreating from the physical world, finding solace, distraction and even digital immortality through the videogames they play. ${ }^{i}$ Unlike the fragile human body, a videogame avatar can survive multiple virtual deaths. In a videogame, kicks, punches, bullet wounds, even decapitations, can all be undone, the virtual body resurrected and the game re-played. These immortal virtual bodies operate in an alternate moral arena in which the player's joy is frequently tied up with inflicting symbolic violence.

See this fella he does that. See this fella he kicks him. See now. Hit. That button. Go on. Now. Now. Now. A back flip. Isn't it mad? Isn't it brilliant. I say. It is. ... Bash him hard into the floor. You saying left one right one that's it now and more forward get the hang. I. Hours of it. Hours of fun. ... It's stupid game. It is. It is. Is it not life and death. ${ }^{\text {ii }}$

The unnamed boy in A Girl is a Half-Formed Thing is giddy with pleasure as his on-screen double punches, kicks, and pins his opponent, punctuating McBride's prose with strikes on the keyboard and jerks of a joystick. His enjoyment becomes an obsession and the more he plays the better he gets. Better at kicking, better at hitting, better at killing in those endless 'Hours of fun'. For the boy's mother, however, these are lost hours, unproductive and morally questionable. The computer, as she sees it, is for 'further education' and futuristic work done by enigmatic 'analysts in rows in shirts' iii While certainly not in the way his mother had imagined, the computer in this novel is, unquestionably, a site of learning and, consequently, a repository of memory. At the very least, a successful videogame player must remember how they have played before in order to do better next 
time. Remembering strategies, locations, and keypad combinations allows the player to progress further in a game each time he or she plays. But there is something more than this simplistic cycle of recall and repetition which concerns me here, namely, that videogames alter the way we experience a virtual past. Conventional analyses of videogames make a distinction between the human player operating the computer and the onscreen character who represents him or her within the game, the avatar. The avatar and the player have a complex relationship which varies according to several factors, including, the type of game played, the environment and context in which the game is played and the experience and skill of the person playing. In the three Irish novels discussed here, fictional characters are depicted playing both real and imagined videogames featuring a number of avatar perspectives. In the earlier videogames, such as those referenced in $A$ Girl is a Half-Formed Thing, players view a side-on, cartoonish avatar, limited to the frame of the screen and the physical movements of hand-to-hand combat. By contrast, in Here Are the Young Men, characters are portrayed playing contemporary first-person shooter games in which the photorealistic action is seen as if through their own eyes. Skippy Dies features a quest style game in which an elf-like protagonist stands in as the player's digital other. Notably, in all of these novels, players suspend their disbelief so far as to over-identify with their avatars, jeopardising their sense of self in the process. Such a blurring of player and avatar raises several questions about how memory is experienced, articulated, and mediated. Do an avatar's actions subsequently become a player's memories? Does playing videogames alter memory or shape the way a player interacts with the past? And perhaps most crucially, when an avatar stabs, punches, or shoots an opponent, does the player remember that act of violence as a witness or a collaborator?

\section{Level 1: Bash him hard into the floor}

Necessarily a relatively recent phenomenon, videogames are often represented in literary fiction as a form of allegory or mythology. Tropes of fantasy, science-fiction, and horror may enter an 
otherwise realistic narrative via the games consoles of characters without jarring genre conventions. Equally, when characters play videogames in novels their actions permit thematic and structural experiments, inviting the author to explore non-linear time, alternative lives, and unreliable memory. While the games played in novels are in themselves rich in interpretive potential, the player-characters are revealed to us uniquely unguarded during the act of gameplay. More conscious than in a dream, less censored than in a conversation, a character's behaviours and motivations are clarified or distorted as they manipulate an avatar. In Rob Doyle's debut novel Here Are the Young Men (2014), Kearney, a crude and increasingly unstable eighteen-year-old, is highly influenced by videogames, not only playing well-known titles but also designing his own games. Riffing on the cliches of well-known videogames and real-world violent contexts he imagines the game Provos!

Ye have to start shootin loads of Proddy fuckers in the street in front of their families and everything. Then ye have to plant bombs in shopping centres and all, and shoot yer way out if the RUC get wind of ye. And when yer coming to the end of the game, it switches over to England, ye have to start taking the war to the Brits ... the last fuckin mission is ye have to assassinate the queen. ${ }^{\text {iv }}$

Later in the novel, Kearney's notebook reveals a longer list of fantasy videogames, including: 'Sexkrime where you play a rapist in a squalid inner-city high-rise.... Alcoholocaust, merging autobiography and zombie-slaughter, an atmospheric first-person shooter set in Dublin' ${ }^{\mathrm{v}}$ There is parody here but the imagined videogames are also plausible, allowing Doyle to test the limits of censure and disapproval. If produced, these games would surely draw media outrage; imagining them within a novel, however, is apparently legitimised. Their function in the narrative is clear, providing a shortcut to the mind of the repellant character. Kearney's imagined videogames are deliberately disturbing, even without the sensory stimulus that an actual game would involve. In a literal sense, there is nothing to see here, the game must be conjured in the reader's imagination. Indeed, this is exactly what Kearney does throughout the novel. When not playing videogames he projects the violence from games onto real life; on the bus to school, for instance, 'he slaughters everyone onboard ... as gunfire tears through the upper deck, blasting out windows, ripping 
children in half amidst howls of terror' ${ }^{\text {vi }}$ These imagined acts of violence on the one hand, and simulated acts of violence in videogames on the other, gradually move closer and closer together in the novel, culminating in deadly consequences.

Violent videogames and debates about their influence on young people have existed for as long as home computers have been commercially available. Reactions to the 1976 game Death Race capture the tone of the early commentary. Inspired by the dystopian American film of the same name, the game depicted:

a cross-country road race where contestants run down and kill pedestrians for points. People in wheelchairs are the most valuable prey, earning the contestants a hundred points, elderly people seventy points, and adolescents only $30{ }^{\text {vii }}$

Condemned in the US, the National Safety Council described the game as 'sick and morbid' leading to televised discussions on the psychological impact of videogames on young people. ${ }^{\text {viii }}$ While the premise for the game is undeniably disturbing, in our own age of increasingly realistic computer generated images, it is almost inconceivable that this game could be interpreted as so morally threatening. Limited by early computer graphics, the simple geometric white shapes on a black background which constitute Death Race look more like a remedial cross-stitch sampler than a scene of mindless violence. This early period of videogaming, described as the 'Atari Era', was characterised by games featuring 'Abstract Violence', "considered to be "violent" because they portrayed smaller blips destroying larger blips'. ${ }^{\text {ix }}$ As the moral panic surrounding Death Race demonstrates, it is not seeing or even playing violence that threatens harmful real-world consequences but imagining it. With limited visual stimulus, the gamer must project meaning onto these basic symbols, either using memories of images from the related film, or from his or her own imagination. In simple terms, the violence is in the gamer not the game. Yet as Clive Thompson observes, the paradoxical argument 'that games either brainwash us into violence or are harmless fantasies ${ }^{\text {x }}$ persists, fuelling a relentless media 'preoccupation with the assumed dangers of videogames' ${ }^{x i}$ Those who argue that videogames can 'brainwash' see violent games as leading to desensitisation, even an altered morality. Such concerns are not so much with what the player 
imagines during gameplay, but what they might remember, consciously or otherwise, afterwards. In this reading of videogames, playing creates a false memory in which violence experienced or perpetrated by the avatar is, in effect, experienced or perpetrated by the player.

In many ways, videogames are all about memory; the game and console remember the player's progress, the player remembers what their avatar should do next and what not to do again, their muscles remember the precise combination of thumbs on buttons, eyes on pixels. This concept, an aspect of 'digital memory', is considered in this essay across two contexts: the machine and the mind. In the first instance, digital memory is understood here as both the generation and preservation of data. In the broadest sense, everything we create and store using computers can be understood as contributing to the phenomenon of digital memory. Secondly, digital memory is read as a new manifestation of human memory in response to the digital age. How has the ubiquity of digital technology begun to change what, where and how we remember? These two aspects frequently intersect resulting in artefacts of digital memory such as:

Online mementos, photographs taken with digital cameras or camera phones, memorial web pages, digital shrines, text messages, digital archives (institutional and personal), online museums, online conference message boards, virtual candles, souvenirs and memorabilia traded on eBay, social networking and alumni websites, digital television news broadcasts of major events ...blogs, digital storytelling, passwords, computer games based on past wars, fan sites and digital scrapbooks. ${ }^{\text {xii }}$

As this list suggests, manifestations of digital memory can be unsettlingly broad, encompassing 'the ordinary and mundane as well as the traumatic and newsworthy.' ${ }^{\text {xiii }}$ While the examples cited here are all characteristic of the last few decades, they are also, of course, just the latest versions of longestablished human habits. Since humans produce more data than their brains can store they are compelled to find alternative ways to preserve and transmit memory. Early civilisations acknowledged the frailty of human memory by creating objects and later texts as alternatives sites of memory using stone tablets, written manuscripts and later and then printed books. To some extent the development of digital memory is a continuation of this and part of the ongoing drive for immortality by 'outsourcing the contents of our minds to ever more durable, compact, and portable objects' ${ }^{\text {xiv }}$ For Abby Smith Rumsey, the current age of digital memory is simply the latest example 
of 'information inflation', a tipping-point at which we risk becoming overwhelmed by our own ingenuity. ${ }^{\mathrm{xv}}$ The perceived threats surrounding digital memory are typically shaped around three factors: scale, pace and fragility. Certainly, the rate at which digital data is generated, and, therefore, the volume that needs to be stored is beyond lay imagining. More significant, however, is the gap between the perceived durability of digital memory and the reality of its impermanence. As Rumsey warns, 'Digital memory is ubiquitous yet unimaginably fragile, limitless in scope yet inherently unstable. ${ }^{\text {xvi }}$ In practical terms, digital memory is reliant on storage formats and devices which rapidly become obsolete. Equally, all manifestations of digital memory, including the now pervasive social networks, blogs and computer games, require a reliable power source and stable internet connection to function. We ignore the precarity of the digital, perhaps because we cannot comprehend the consequences of it failing us.

Paul Murray’s Skippy Dies (2010) bears out the spoiler of the title in the opening pages when schoolboy Daniel Juster, or Skippy, appears to choke to death in a doughnut eating competition. Murray's novel is set in a present-day Irish school, where boys huddle 'around the Nintendo' ${ }^{x v i i}$ warmed by their 'digital hearth' ${ }^{\text {xviii }}$ For the boys who board in the elite Dublin boys' school in which the novel is set, videogames provide both private solace and communal bonding, adding domestic familiarity to the institutional setting. As Bernadette Flynn contends, the focus of the domestic gaze, once trained on the fireplace, then the radio, then the television, is now drawn to the games console. ${ }^{\mathrm{xix}}$ By their nature, videogames are narratives of conflict and contest and these ideas are reflected in the multiple battlefields of Skippy Dies. From the classrooms and corridors of the school, through the virtual worlds of their videogames and finally to the massacres of the First World War discussed in their history lessons, the boys are surrounded by real and symbolic acts of violence. History teacher Howard's efforts to draw Skippy and his classmates towards the alternative narrative of Irish soldiers in the First World War stands in direct challenge to the mesmerising warmth of the screen. For the contemporary Irish schoolboys in this novel, videogames offer a legitimised space to fight, standing in for the wars of previous generations. Yet 
they are also a place of sanctuary; a way to keep the digital home fires burning. Textbook history and acts of remembrance are perceived by the schoolboys as the equivalent of 'Atari era' games, black and white and, frankly, boring.

They live in a continuous sugar-rushed present, in which remembering is a chore left to computers, like tidying your room is a chore left for the Third World maid. If the war briefly caught their imagination, it was only as another arena of violence and gore, no different from their DVDs and video games. ${ }^{\mathrm{xx}}$

If World War I fails to catch the imagination of the class, teacher Howard is absorbed to the point of obsession. In the very act of teaching this topic, he draws attention to the First World War's status as 'marginalised to such an extent that it is characterised by a combination of forgetfulness and embarrassment' in the history of both the Free State and the Republic. ${ }^{\text {xxi }}$ Indeed, it is precisely this absence of memory that Howard hopes to correct. Initially at least, the teacher's efforts to help the boys access material sites of remembrance are comically thwarted. An impromptu school trip is undermined when the National Museum admits to having nothing related to the War on display and the Memorial Gardens at Islandbridge are anti-climactic, positioned 'between a scrap merchant's and a mental institution'. ${ }^{x i i}$ Nevertheless, the boys very presence in the 'isolated and rarely visited' yet 'beautiful and symbolic gardens' is significant, precisely because the location forms 'part of Ireland's numerous inactive geographies of memory. ${ }^{\text {xxiii }}$ Standing together in the gardens the boys receive a lesson in memory, coming to understand that 'representations of the past are coloured by the views of the rememberer'. ${ }^{\text {xiv }}$ If the relatively distant past of World War I is inaccessible and irrelevant, the recent death of their classmate Skippy remains visceral. United in communal grief, the boys stand in the memorial park, transformed into ghostly avatars of their ancestors:

in their grey uniforms for all the world like an incorporeal platoon, materialised out of the winter clouds to scour the bare park for someone who has not forgotten them. ${ }^{\mathrm{xxv}}$

For history teacher Howard at least, the parallels between the generations of young Irishmen are self-evident, not least in their shared appetites for 'violence and gore'. The contemporary boys revel in the simulated violence of their screens, just as their ancestors were incited to 'play up, play up and play the game!' This jingoistic convergence of playing a game and fighting a war is disturbing, not least because it seems to target a particular kind of boyish naivety; as if trench warfare were 
really no more than a game of rugby union that has got a little out of hand. ${ }^{\mathrm{xxv}}$ The experiences diverge, inevitably, at the point of consequences; playing at war is not the same as fighting in one. And yet, if your brain and body experience the rush of adrenaline, your finger pulls the trigger, your eyes see the consequences of your actions, is this not, on some level, an experience stored as a memory? Each time the virtual experience is repeated and recalled, the more compelling the memory becomes, yet also, the further it strays from the original version. As Rumsey explains:

During recollection, a memory is opened up like a book or computer file, gets reworked, then receded and stored in a slightly modified way ... Recall is literally a rebuilding process, executed chemically, and new perceptions are incorporated into the old. ${ }^{\text {xvii }}$

Memory is iterative but also cumulative, each act of recall building on the last. In his essay on 'Digitising Historical Consciousness', Claudio Fogu imagines a fictional videogame, 'Holocaust II', as the source of a thought experiment. As Fogu argues, the playing of such a game, based in historical reality and experienced through immersive gameplay, 'would surely provide virtual memories of something perceived as real.' ${ }^{\text {xxviii } ~ ' V i r t u a l ~ m e m o r i e s ', ~ F o g u ~ h y p o t h e s i s e s, ~ a r e ~ l i k e l y ~ t o ~}$ be created by gameplay, rather than via other media such as film and television, because of the distinguishing element of 'action' ${ }^{x x i x}$ The player of a videogame does more than witness, he or she participates, their 'work' is 'a mixture of the physical and the mental.' ${ }^{\mathrm{xxx}}$ Whereas an audience in a theatre observes a drama unfold from their seats, the videogame player must take to the stage, improvising, reacting to co-actors, using the props and responding to the changing scenery. This analogy might be taken even further since, for all the ingenuity and reflexivity required of a videogame player, the action is necessarily pre-scripted by the game's designers. Far from being spontaneous or deviant then, violent acts in videogames are, inevitably, pre-programmed. As Cameron Loyd Grey explains:

The player may bomb a corporate headquarters and thus release some of his suppressed rage in a virtual environment, but he is following a script much more than he is an active creator of his own adventure ${ }^{\mathrm{xxxi}}$

In this reading, acts of gratuitous virtual violence are seen as displacement activities, an acceptable means of releasing frustration or dissipating anger. The act itself, throwing a person from the top of 
a high-rise block, driving into pedestrians on the pavement, shooting police officers in their car, is permitted, even prescribed, within the rules of the game. Since the actions are scripted the player's moral culpability is arguably ameliorated. Rather than viewing violent games as dangerously suggestive, this reading attempts to disassociate the act of virtual violence from its real life equivalent. In this interpretation, a player on a killing spree in Grand Theft Auto can no more be seen as preparing to do the same in real life than a chess player can be accused of rehearsing high treason

\section{Level 2: Hours of Fun}

In his review of $A$ Girl is a Half-Formed Thing, James Wood describes McBride's 'blazingly daring' novel as set in 'an Ireland shorn of dates and obvious historical specificity', only conceding that the presence of a Walkman hints at the 1980s. ${ }^{\text {xxii }}$ But what about the computer? Are computers and games consoles really so ubiquitous as to have become invisible to readers? Contrary to Wood's sense that it is a timeless narrative, the arrival of the first computer in this Irish home dates McBride's novel precisely. ${ }^{\text {xxiii }}$ Unquestionably, the arrival of the new computer fractures the already strained family structure, annexing the son/brother to his bedroom and away from the communal domestic spaces. When the mother complains of her evenings 'sitting down here on my ${ }_{\text {own }}{ }^{\text {xxxiv }}$ while her children are upstairs playing videogames, she highlights the way in which computers change how and where we spend our time. In the way that previous generations marvelled at 'labour-saving devices', our own age may be defined by 'memory outsourcing' machines, devices which paradoxically save us time while consuming it all. One might assume that outsourcing our mundane memories, phone numbers, directions, and dates, say, to our devices, creates space for more complex and emotionally sustaining memories. If only the human brain were this compliant. Memories, however spontaneous they may seem, are, in fact, 'constructions mediated by means of complex psychical and mental processes. ${ }^{\text {xxxv }}$ The use of digital technology has not changed how we remember but it has affected what we expect to remember. We have 
abandoned all kinds of memory-work, safe in the knowledge we can easily find the information online. Having a so-called 'good memory' in the digital age is 'less a question of remembering and more a matter of [knowing] where to look. ${ }^{\text {xxxvi }}$ That A Girl is a Half-Formed Thing is set at the early stage of this co-dependent relationship with computers is significant. All computers are a memorial to both past and future, a reminder of the fissure between what was and what will be possible. Here, for example, the technology which seems thrillingly futuristic to McBride's characters is already quaint to her readers. For the son/brother character a clear distinction is made between the way he spends his time in the Before Computer epoch, and after it. While the mother continues to insist that playing games on a computer is a waste of 'God's good fruits', its impact cannot be undone. ${ }^{\mathrm{xxxvii}}$

If playing videogames is a waste of time, the way they disrupt time is all the more subversive. In part as a reflection of this, all of the novels considered here operate within unconventional narrative timeframes. Murray's novel starts with the death of his protagonist on the front cover, subsequently working back from the denouement. Doyle's novel is a retrospective account of a summer made up from the multiple perspectives of suicidal, drug-fuelled, and lovesick teenagers. McBride's novel is notoriously experimental in structure and form, toying with childhood recollections and counter-nostalgia. Although in different ways, they might all be thought of as novels of memory, that is, texts which face up to the clash between chronological history and memory as circuitous and associative. In these novels, memory rushes in at pace, coming in unbidden flashes before being slowed down, repeated and editorialised for private comfort or sanitised for public consumption. The instability of memory means that it is already a subversion of the traditional historical narrative 'commonly understood as the unfolding of events in broadly linear fashion' within a 'cause and-effect structure'. xxxviii Crucially, these novels reject such a limited and limiting structure by engaging with both remembering and forgetting. Information, data if you prefer, must be rationalised and filtered, connections made and extraneous details rejected. Remembering, in other words, is also a question of forgetting since 
any attempt to save memory always entails loss and forgetting as well as additions and supplements. We save our pasts only as something else: something different, something less than, something more than. ${ }^{\mathrm{xxxix}}$

Videogames are employed by these novelists precisely because they portray a temporary forgetfulness of the real world and the dual memory landscapes of life within and beyond the game. Structurally, videogames feature as a simultaneous plot strand, character and avatar progressing through multiple temporal levels. Throughout Murray's novel, for example, Skippy plays a fictional videogame, Hopeland, incrementally overcoming trials, moving towards the final salvation of the inevitable princess. In his off-screen life, Skippy's quest for the beautiful but troubled Lori stands in obvious parallel. Whether in the game or out of it Skippy must fight, search, overcome. That said, when gripping tightly to the controller of his Nintendo, Skippy is able to enact the kind of heroism not possible in his real life. Physically connected to the game through his hands on the buttons and his eyes on the screen, Skippy becomes cut off from the real world as 'the circuit of affection and logic that passes from computer to player and back closes onto itself' ${ }^{x l}$ Skippy is fully absorbed in the game, not because he is unusually susceptible but because of the digital's unique 'ability to make us forget the medium, and thus achieve an immersive effect of presence (immediacy)'. ${ }^{\text {xli }}$ While Skippy's game play is clearly an act of escapism, it might more accurately be thought of as virtual embodiment since Skippy 'becomes' Djed, the avatar of Hopeland as he plays. While Murray describes the landscape and aesthetic of Hopeland in some detail, we only really 'see' Djed when Skippy adopts his form at the Halloween Hop, wearing 'his runners, fitted out with tiny wings' and 'crepe-paper hunting hat' ${ }^{\text {xlii }}$ Skippy's embodiment of his videogame avatar speaks to the comfort he finds hiding behind and within him. Equally, in his schoolyard fight with bullying sociopath Carl, Skippy imagines enacting Djed's onscreen moves. His inner voice offering advice learnt from the game, 'every Demon has a weak spot' ${ }^{\text {'liii }}$, Skippy frantically tries to remember: 'the forward roll

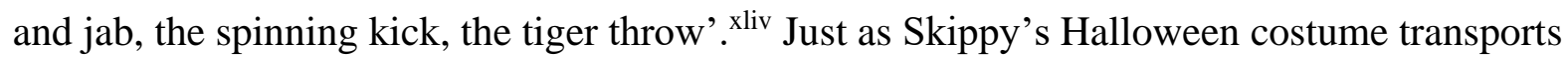
Djed's capacity for adventure from the computer screen to the school hall, during the real fight, his 
movements echo what Taylor calls the 'embodied experience of fighting in computer games' and the 'duality of presence' of the self in and out of the game. ${ }^{x l v}$ In the act of playing, that is, the player becomes unreal, a work of fiction, their cyber-body 'a confluence of machine and flesh'. ${ }^{\text {xlvi }}$

Just as Skippy brings his avatar out from the screen, the brother in A Girl is a Half-Formed Thing, attempts to move the virtual violence from the screen to his own body saying: 'I think I'd like to kick like that. I practise it when there's no one in. I hiya'd the clothes line and it broke'. ${ }^{\text {lvii }}$ While the emulation of videogame violence may seem childish it is, in many ways, an appropriate response to the immersive experience. To play successfully, to win, the player must collaborate with the computer, learning to think and behave in the way the computer demands. The pleasure of play, one might argue, depends upon the player melding with the computer, sharing its thought processes. As the adult brother and sister share videogames in McBride's novel, they return to childhood play and the sibling alliance which has protected them from their mother. Their regeneration as playmates also marks a further shift in the novel's complex timeframe. As the Girl gets older and more independent of the controlling family unit, her brother's brain tumour makes him younger, a little boy again and eventually, a baby in nappies needing to be spoon-fed. The videogames they play are a component of this narrative, creating an imagined other, the man he is never to become; a man who might use computers for work in contrast to the boy who only uses them for play and fantasy.

Mad lust of it you get for computer games go blip across a screen. That's your eighteenth birthday gift improve your mind with... The new love take up all your time. Eating sweets and Jupiter Landing. Come on and have a go. No. I don't want to. It's killing all your brain cells. So? ?lviii $^{x}$

The videogames aren't killing his brain cells but they are dying all the same. Jupiter Landing, one of the early videogames available on the Commodore 64 computer, challenges players to probe the planet's surface, carefully navigating the folds and valleys of the dark landscape, not unlike the surgeons who concede in their efforts to root out the invading tumours in the boy's brain. The destruction of his brain, caused both by the tumour and the various operations which fail to remove it result in a hardware memory fault; the brain is simply unable to process memory as it once did. 
Somewhat more conventionally, Skippy's initial failure to recall and comprehend that he has

suffered sexual abuse is represented by Murray as a suppressed trauma. The abuser's attempts to erase Skippy's memory by giving him drugs are ultimately unsuccessful, not least because it is in a drug-fuelled fugue that Skippy's memory returns as he finally completes his videogame. For both boys, the attacks on their memory induce a state of hopelessness and understandably so. As Rumsey makes clear:

Our memories are not just an accumulation of data points about the past. They are the very fabric of the self, woven of our experiences, endowing us with time, place, personality, and identity in the world. ${ }^{\text {xlix }}$

\section{Level 3: Is it not life and death}

Whereas Skippy primarily plays a fictional videogame, Kearney and the other characters in Here are the Young Men play well-known titles, available for any reader of the novel to purchase and play. This effective use of 'in-game footage' within the novel assumes a level of games literacy among readers regarding the types of games played and the culture of group gameplay. An assumed knowledge of gaming imagery is most apparent when the perspectives of the novel's protagonists and the game's avatars merge:

Kearney finished off the whore in the pink miniskirt with a crack of a baseball bat to the skull, then shot her in the face for good measure ... switching to the shotgun as he reached the street corner. He hoisted the gun to waist height and fired. A circular flash of blood coloured the murky middle distance. ${ }^{1}$

Although the syntax indicates Kearney, a fictional character from the novel, is on a killing spree, the reader understands that these are, in fact, the equally fictional actions of his on-screen avatar. References to these infamous videogames, here Grand Theft Auto, and elsewhere Manhunt and House of the Dead provide different layers of meaning to readers depending on their familiarity with gaming. A non-gamer might take these for equally constructed titles, another fictional prop. An experienced gamer, meanwhile, would immediately recognise Manhunt as a game banned in several countries due to 'scenes of blood and gore that go beyond strong'; ;i just as they would 
identify the specific acts of violence later perpetrated by Kearney as echoing stock in-game behaviours. It is not only the acts of virtual violence, of course, but the nonchalance with which they are committed which Doyle makes use of here. The violence committed by Kearney's avatar is recognisable, characteristic even, of certain types of videogames. Inside the frame of the game at least, these actions are authorised by the 'procedural models' and 'imagined systems' which create 'spaces for play'lii. That is, the internal logic of the game supersedes the moral code and law that exists beyond it. In some cases this manifests as a direct inversion in which actions condemned as abhorrent in real life are rewarded within the context of the game, shooting someone in the face say, or hitting someone with a baseball bat. As Fogu argues, 'gaming is a matter of role-playing, simulation, immersion, and interaction, not representation. 'liii It is all just pretend. Perhaps, but the representation of gaming is about representation. When Doyle lifts acts of virtual violence outside of the frame of gameplay and places them within a novel, the actions of the avatar-character are given an alternate meaning. Kearney's growing obsession with videogames, the way violent motifs leak from the screen into his life and the eventual breakdown of the distinction between the real and the virtual are at the core of Here Are the Young Men. Since there is ultimately little distinction between how he behaves as a character and how he operates an avatar, Kearney's actions, thoughts and fantasies can be said to go beyond simple 'role-playing'.

Although Doyle's novel draws out this rather crude comparison — player of violent games turned increasingly violent - it is not so reductive as to present this as the only explanation for Kearney's actions. Set in the summer after their Leaving Cert, the young men of Doyle's novel are as self-absorbed as they are self-destructive. Uncertain about the future and disillusioned in the present, their days are a blur of videogames, alcohol and drugs. For Kearney, videogames offer a warped salvation from chronic aimlessness, 'not just exciting and absorbing but something grander, almost a spiritual activity' liv Videogames, in other words, provide meaning and structure otherwise absent in the lives of these young men. As a result, the associated violence, whether imagined, simulated or actual, is portrayed as a consequence of a perceived crisis in Irish masculinity. ${ }^{\text {lv }}$ The 
novel is clear in portraying Kearney as the exception, an extreme case among benign peers. Yet there is also something distinctly unsettling in the way videogame violence mutates so organically into actual violence for this character. As Alloway and Gilbert observe: 'perhaps the most disturbing feature of the gaming culture [is] the way that it so powerfully and seductively coalesces images of masculinity and violent action'. ${ }^{\text {vi }}$ As one act of obscene violence simply inspires another, Kearney's murder of a schoolboy with Down Syndrome gruesomely mirrors the combination moves of a videogame, limbs moving smoothly in the perfect sequence to deliver the fatal blow:

Kearney didn't hesitate, nor did he think about what he was doing. He shot his leg in behind the boy's calves, then turned and simultaneously gave him a forceful shove.... He just had time to cry out, and then the back of his head cracked on the sharp edge of the lowest step. ${ }^{\text {lvii }}$

Here Are the Young Men is a coming of age novel in which the children have no desire to grow up. Kearney's obsession with violent imagery and media increases as the novel progresses so that, as other characters' thoughts turn to college, he is absorbed further and further into the screen. Simply put, playing at death so relentlessly finally overloads Kearney's brain until he is unable to make the distinction between the virtual and the real. His real-life murder of two homeless men marks the transfer of videogame violence to his own body, although he continues to think of his actions as 'like a game'. ${ }^{\text {viii }}$ Kearney is a proficient gamer because he has repeated virtual actions over and over, learning from the game and then re-writing history by forcing the avatar to do what is required. As Doyle's novel suggests, however, failure to distinguish between appropriate behaviour within and beyond the game is potentially destructive. Kearney's obsessive gameplay alters him, creating a faux-traumatic past as a result of the virtual violence he repeatedly witnesses and enthusiastically perpetrates. Playing violent videogames gives Kearney a sense of invincibility because his avatar provides him with licence to inflict harm without being hurt in return. His reckless disregard for the lives of others is a further symptom of his perceived immunity against the kind of violence he enacts both digitally and physically. More than this, Kearney's desire to kill, on screen and on the streets, is a perverse form of self-preservation, a quest for immortality, or, more precisely a deferral of his own death. 


\section{Game Over?}

In the end, Kearney's violence is meted back to him; when his friends discover his actions they conspire to kill him. His death is suitably gruesome, after drinking a concoction heavily-spiked with illegal drugs, Kearney appears to dance into a fire, his organs shut down, his body is mutilated.

Kearney's entire face was charred black, with pink globs dripping over the singed, smoking mass of flesh. His hair was still ablaze. One of his eyes had burst in the heat, but the other gazed up at the night and all its stars. ${ }^{\text {lix }}$

The dramatic end of Kearney's life is presented as a case of tragic inevitability. His friends take his life with an apparent moral impunity; murdering for the collective good, their act of violence presumably preventing many more. Here Are the Young Men begins as a novel fixed in the memories of a life-changing summer, the post-school bridge between youth and adulthood. What transpires is a series of tragedies and disillusionments. Whereas mainstream narratives of youthful summers stand upon nostalgic foundations, Doyle's novel is populated by characters desperately trying to forget. Understandably, these young men want to forget their knowledge of Kearney's crimes, as well as their contribution to his death. One of the challenges of living in the digital age explicated by this novel is precisely this conflict between the solace of forgetting and the reverence, even mania, 'for capturing, storing, retrieving and ordering' memories. ${ }^{\mathrm{lx}}$ It is hugely significant that when Kearney poisons and beats to death homeless men he simultaneously makes a video of the event on his smartphone. Rather than thinking of this footage as incriminating evidence, Kearney's warped pleasure is found, not only in the act of violence itself, but also in the capacity to watch and re-watch it onscreen. The digital memory of his crime, the 'recording, retrieving, stockpiling, archiving, backing-up and saving' of a murder captures the extent to which 'information loss' has become 'one of our greatest fears of this century.' ${ }^{\text {'xi }}$ Fiction creates a space for exploring these ideas in extremis, so that even digital memories we might assume to be unconscionable are preserved. Is this novel a morality tale then? Certainly Doyle extends the question of influential videogame violence to dystopian proportions, but this is surely for the purposes of provocation rather than 
social commentary. Here Are the Young Men is certainly not a technophobic novel but it is cognisant of the ways videogames might prompt trauma as well as catharsis.

While Kearney is alone in his direct adoption of ludic violence, all of the player-characters considered here are lost in some way to the games they play. Their immersion in the world of the game and confluence with the onscreen avatar is a rejection, or at least a deferral, of reality. As Djed, Skippy performs a masculine authority and physical autonomy denied him in real life as a victim of sexual abuse. The brother in A Girl is a Half-Formed Thing kicks and punches against the weakness of his physical body through the jagged pixels of his onscreen others. Both look to videogame avatars for an alternate body, a stronger, braver, invincible shape. Kearney, in Doyle's Here Are the Young Men, takes this to its horrifying extreme, irrevocably forgetting the difference between a game and reality when he pushes a boy to his death in, of all places, the Garden of Remembrance. Digital memory is not immortal either. Quite apart from the fragile infrastructures of storage and power discussed above, computers are vulnerable to viruses, leading to 'a loss of memory and a digital amnesia that makes digital memory just as fallible and unstable as human memory. ${ }^{\text {lxii }}$ While the threats to digital memory are well-worn topics in the fields of computer and information sciences and, increasingly, digital humanities, much is to be done to expand these topics into the full range of memory studies scholarship. The so-called 'turn to memory' with its associated emphasis on trauma and 'oral history's quest to retrieve the memories of groups whose histories had previously been neglected'lxiii has much to contribute here, not least in regard to the tensions between individual and collective memory in the digital context. In the novels discussed here, the family, schools and the church, are complicit in the boys' fates, yet rarely called to account. After all, it is far easier to confer blame on the abstract category of the 'media' or the experienced scapegoat that is violent videogames than any of these venerated institutions. With diseased brains unable to remember or drugged brains able to remember all too clearly, all three boys die. Whatever acts of violence they have played at, imagined or committed via their avatars, their physical bodies remain all too vulnerable to attack. Importantly, and in contrast to reality, in a 
videogame, death is an invitation to simply try again; the more the avatar dies, the better the player becomes. ' ${ }^{\text {'xiv }}$ For both real and fictional gamers, the onscreen epitaph 'Game Over' is not an end at all, but rather a prompt to memory, an invitation to try again, to do better. In a videogame at least, 'one dies so that one may live. ${ }^{\text {'1xv }}$ 
Notes 
' The term videogame is used throughout this essay, rather than the more recent coinage 'digital game', to indicate the full historical range of computer games referred to in the novels under discussion. While digital games are now played via a range of devices, including most recently the smartphone, videogames are typically associated with consoles such as the Nintendo Xbox or Sony PlayStation. The essay's title is drawn from the Nintendo's quit screen, with its (unintentionally) profound warning to players: 'Everything not saved will be lost'.

ii Eimear McBride, A Girl is a Half-Formed Thing (London: Faber \& Faber, 2013), p.91.

iii McBride, Girl, p.80.

iv Rob Doyle, Here Are the Young Men, (London: Bloomsbury, 2014), pp.8-9.

${ }^{\vee}$ Doyle, Young Men, pp.34-5.

vi Doyle, Young Men, p.25.

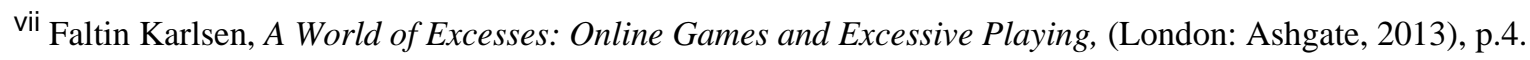

viii Karlsen, World of Excess, p.5.

ix Steven J. Kirsh, Children, Adolescents, and Media Violence: A Critical Look at the Research, (Thousand Oaks: Sage Publications, 2006), p. 229.

x Lucien King, ed., Game On: The History and Culture of Videogames, (London: Laurence King Publishing, 2002), p.24.

xi Jesper Juul, Half-Real: Video Games Between Real Rules and Fictional Worlds, (London: MIT Press, 2005$),$ p.21.

xii Garde-Hansen et al, Save As, p.4.

xiii Joanne Garde-Hansen, Andrew Hoskins, Anna Reading, eds., Save As...Digital Memories, (Basingstoke: Palgrave, 2009), p.1.

xiv Abby Smith Rumsey, When We Are No More: How Digital Memory is Shaping Our Future, (Bloomsbury: London, 2016), p.3.

xv Rumsey, When We Are No More, p.4.

${ }^{x v i}$ Rumsey, When We Are No More, p.4.

xvii Paul Murray, Skippy Dies, (London: Penguin, 2010), p.25.

xviii Bernadette Flynn, 'Geography of the Digital Hearth' in Information, Communication \& Society, 6.4 (2003), pp.551576.

${ }^{\text {xix }}$ Flynn, 'Digital Hearth', p.561.

${ }^{\mathrm{xx}}$ Murray, Skippy, p.541.

xxi John Morrissey, 'Ireland's Great War: Representation, Public Space and the Place of Dissonant Heritages' in Journal of the Galway Archaeological and Historical Society, 58 (2006), p.100.

xxii Murray, Skippy, p.552.

xxiii Morrissey, 'Ireland's Great War', p.103. 
xxiv Susannah Radstone, 'Reconceiving Binaries: The Limits of Memory' in History Workshop Journal, 59 (2005), pp. 134-150, p.135.

${ }^{\mathrm{xxv}}$ Murray, Skippy, p. 557.

xxvi This apparently irresistible conflation is sustained through the old cliche of the battle of Waterloo being won on the playing fields of Eton and the compelling story of the Dublin Pals signing up and training for war at Landsdowne Road.

xxvii Rumsey, When We Are No More, p.114.

xxviii Claudio Fogu, 'Digitalizing Historical Consciousness' in History and Theory, 48. 2, (2009), pp. 103-12, p.105.

${ }^{x x i x}$ See Alexander R. Galloway, Gaming: Essays on Algorithmic Culture, (Minneapolis: University of Minnesota Press, 2006).

xxx Sarah Cameron Loyd Grey, 'Dead Time: Aporias and Critical Videogaming', Symplokē, 17.1-2 (2009), pp. 231246. p. 241.

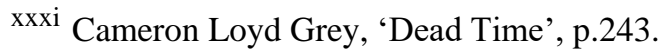

xxxii James Wood, 'Useless Prayers: Eimear McBride's A Girl Is a Half-Formed Thing', in New Yorker, Sept 292014.

xxxiii The computer in McBride's novel seems to be the Commodore 64, a hugely popular early home computer, selling over 17 million machines between 1982-1993. For more on the early years of Home Computing see Centre for Computing History http://www.computinghistory.org.uk/det/1336/commodore-64 (accessed 10/06/16).

xxxiv McBride, Girl, p.104.

xxxv Radstone, 'Reconceiving Binaries', p.135.

${ }^{x x x v i}$ Andrew Hoskins, 'The Mediatisation of Memory', in Garde-Hansen et al, Save As, pp. 27-43, p.29.

xxxvii McBride, Girl, p.105. As the Girl responds, 'I don't think commodores were hanging on the tree Mammy'.

xxxviii Radstone, 'Reconceiving Binaries', p.138.

xxxix Garde-Hansen et al, Save As, p.19.

${ }^{\mathrm{xl}}$ Aden Evens, 'The Logic of Digital Gaming' in Mechademia, 6.1 (2011), pp.260-269, p.266.

${ }^{x l i}$ Fogu, 'Digitalizing Historical Consciousness', p.105.

xlii Murray, Skippy, p.164.

xliii Murray, Skippy, p.358.

xliv Murray, Skippy, p.359.

xlv T L Taylor, Play Between Worlds: Exploring Online Game Culture, (London: MIT Press, 2009), p.109.

xlvi J. Boulter, 'Virtual bodies, or cyborgs are people too', in N. Garrelts, ed., Digital gameplay: Essays on the nexus of game and game, (Jefferson, N.C.: McFarland \& Co., 2005), p.53.

xlvii McBride, Girl, p.94.

xlviii McBride, Girl, p.80. 
xlix Rumsey, When We Are No More, p.131.

' Doyle, Young Men, p.45. The game depicted here, part of the Grand Theft Auto franchise, is restricted by European law to over-18s, the novel which portrays violent scenes from the game, of course, is not.

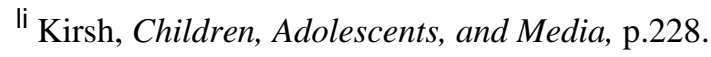

lii Fogu, 'Digitalizing Historical Consciousness', p.118.

liii Fogu, 'Digitalizing Historical Consciousness', p.118.

liv Doyle, Young Men, p.68.

${ }^{\text {Iv }}$ For detailed commentary on this topic see Catherine Rees, ed., Masculinity in Crisis: Depictions of Modern Male Trauma in Ireland (Dublin: Carysfort Press, 2016) and Caroline Magennis and Raymond Mullen, eds., Irish Masculinities: Critical Reflections on Literature and Culture, (Dublin: Irish Academic Press, 2011).

${ }^{\text {Ivi }}$ N. Alloway \& P. Gilbert, 'Video game culture: playing with masculinity, violence and pleasure', in Sue Howard, ed., Wired Up: Young People and the Electronic Media, (London: Routledge, 1998), p.102.

Ivii Doyle, Young Men, p.256-7.

Iviii Doyle, Young Men, p.254.

lix Doyle, Young Men, p.293.

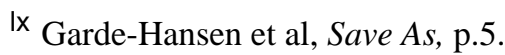

Ixi Garde-Hansen et al, Save As, p.5.

Ixii Garde-Hansen et al, Save As, p.13.

Ixiii Radstone, 'Reconceiving Binaries’, p.138.

Ixiv Gary Westfahl, 'Zen and the Art of Mario Maintenance: Cycles of Death and Rebirth in Video Games and Children's Subliterature, in Immortal Engines: Life Extension and Immortality in Science Fiction and Fantasy, George Slusser et al. eds., (Athens: University of Georgia Press, 1996), p.213.

Ixv Jeffrey Douglas, 'Wooden Reels and the Maintenance of Virtual Life: Gaming and the Death Drive in a Digital Age', in ESC 37.1 (March 2011), p.86. 